\title{
Universities and Export market orientation \\ An exploratory study of UK post-92 universities
}

\begin{abstract}
Purpose - This paper aims to explore how post-92 UK universities perceive and manage market orientation in their export operations of educational services to international students (i.e., export market orientation) (EMO) in the context of international students' recruitment.
\end{abstract}

Design/methodology/approach - Through a case study design, this qualitative research was undertaken amongst 8 post-92 UK universities. Semi-structured indepth interviews were conducted with managers in the international offices of universities.

Findings - The results indicate that EMO in universities consist of information-based activities geared towards foreign markets. Superior knowledge and awareness of the market components is central to the implementation of these information-based activities. This involves market information generation and dissemination, as well as the need for rapid responsiveness due to the changing nature of the higher education market.

Research limitations/implications - The selected methodology makes these results alone unfit for generalising to a larger population. Improved theoretical models are needed for generating more knowledge about the antecedents and consequences of EMO in universities.

Practical implications - The paper believes the findings are particularly relevant for international marketing managers of exporting universities. The current study suggests some implications for international marketing managers when actively managing their marketing activities towards foreign markets.

Originality/value - The paper identifies a gap in current higher education marketing research. The original contribution of the paper is to address this gap so that researchers and practitioners have some understanding of the export marketing behaviour of UK universities in the context of international students' recruitment.

Keywords: Export market orientation, Higher education marketing, Universities, International students recruitment, International marketing managers

Paper type: Research paper 


\section{Introduction}

In recent years, a number of scholars have argued in favour of the marketisation of higher education worldwide (Bragg, 2007; Yokoyama, 2008; Datar et al., 2010). This process of marketisation of higher education is particularly relevant in an international context as higher education is increasingly incorporated into global markets and marketing systems. The higher education sector is facing a rapidly changing and diverse international market, increasingly changing regulations, emerging technologies, and more demanding international students (Hemsley-Brown and Oplatka, 2006). To remain competitive in these turbulent markets, universities are being urged to develop a market orientation towards their export markets (i.e. export market orientation EMO), including recognising the need to develop new service offerings that are timely and responsive to international students' needs. Yet, little extant theorisation in marketing systematically uncovers the process through which universities can manage their marketing activities towards their export markets (EMO). One reason for this lack of attention to the higher education area might be that exporting has traditionally been associated mainly with tangible product industries (Leonidou et al., 2010). As a result, the export marketing literature -despite being rich and well established- may not fully capture the intricacies of higher education services.

To date, the literature into international higher education management has focused on some questions relating to student behaviour (Mazzarol and Soutar, 2002; Binsardi and Ekwulugo, 2003; Shah and Laino, 2006; Paswan and Audesh, 2009; Vauterin et al., 2011). The few studies reviewing higher education in international markets were based on a consumer/student perspective. Yet, there is a paucity of studies examining how strategic managers in universities can develop and enhance their international marketing behaviour (Ho and Hung, 2008) with specific reference to conceptualising EMO (referring to the implementation of export marketing) in the educational setting.

Thus this paper addresses the need to identify how export market oriented universities perceive and manage EMO. Theoretically, we draw on the work of Cadogan et al. (1999) on EMO and explore its relevance to higher education. We focus specifically on post-1992 UK universities in which the potential, at least, exists for both exporting and marketing activities. We aim to contribute to the export marketing literature by investigating a contextually peculiar environment (i.e. higher education) and respond to previous calls for examining EMO from the perspective of international services marketers operating in different sectors (e.g., not-for-profit organisations, nontraditional organisations, organisations in the public sector) (Cadogan et al., 2000; Inglis, 2008). A better understanding of the reasoning underlying this orientation will provide international marketing managers with guidelines for crafting their export marketing strategies more effectively.

This paper has the following structure: the next section outlines the literature pertaining to export marketing and higher education marketing followed by a description of the methods used in this study. The key findings, with a focus on the dimensions that constitute EMO in universities, are then presented and discussed against the marketing literature. Last, limitations and directions for future research are suggested.

\section{Literature review}

\section{EMO}


The concept of EMO was proposed by Diamantopoulos and Cadogan (1996) to extend the application of market orientation to exporting organisations. EMO refers to the implementation of marketing in an export setting (based on Jaworski and Kohli, 1993). According to Cadogan et al. (1999, p.690), EMO consists of three coordinated information based activities, namely, "generation, dissemination and response to export market intelligence. These activities are oriented towards export customers, competitors, and exogenous market influences. Such activities are carried out through a coordinating mechanism".

1. Export intelligence generation. This dimension refers to activities which constitute the creation of export market intelligence (e.g., export market research, export assistance) and which are focused towards export customers, competitors, or the related environmental changes (Souchon and Diamantopoulos, 1996, p.53).

2. Export intelligence dissemination. It includes activities which involve the sharing of export market intelligence (e.g., formal meetings) and which are focused towards export customers, competitors, or the related environmental changes (Cadogan et al., 1999, p.692).

3. Export intelligence responsiveness. It includes the design and implementation of all responses to the intelligence that has been generated and disseminated. Such responses are directed towards export customers, competitors, and the related environmental changes (Diamantopoulos and Cadogan, 1996, p.38).

4. Coordinating mechanism. This reflects a coordinated effort to create superior value (Narver and Slater, 1990) and an organisation-wide responsibility for market-oriented activities (Kohli and Jaworski, 1990) and ensures that marketoriented activities are carried out effectively and efficiently (Cadogan and Diamantopoulos, 1995, p.54).

Conceptualising EMO offered a foundation to the model of EMO. The model suggests that a well developed EMO is associated with superior export performance (Cadogan et al., 2001; Cadogan et al., 2002a; Cadogan et al., 2009). Although EMO has been one of the most influential frameworks in the export marketing literature, it is maintained that the bulk of EMO research is biased towards the traditional physical goods and manufacturing sectors. Relevant investigations of EMO in context-specific markets are almost inexistent. Therefore, our study aims to shed some light on the application of EMO in higher education.

\section{The higher education perspective}

The emergence of the export philosophy in higher education has materialised through the expansion of a business-oriented transnational higher education. For example, in the USA, UK and Australia, there is a significant transnational education characterised by a considerable flow of international students to higher education institutions in these countries to receive education. These nations are said to be primary exporters of higher education (Gürüz, 2012). Revenues of transnational higher education are visible in the balance of payments of many exporters of international higher education (De Vita and Case, 2003; Harman, 2004; Russell, 2005). 
In parallel to these developments, the GATS has included exporting higher education services in its agenda to promote further liberalisation of international trade of higher education services (Martens and Starke, 2008). Based upon models examining the export behaviour of services firms (Clark et al., 1996; Roberts, 1999), and bearing in mind the service nature of the educational offerings (Moogan, 2011), the OECD and the GATS agreements recognise international students' recruitment as the most developed form of export education (Knight, 2003).

The export market is of considerable importance in generating increased revenues for universities (De Vita and Case, 2003; Russell, 2005; Bolsmann and Miller, 2008). With the wave of globalisation and increased liberalisation of trade in services (Verger, 2008), there has been increased competition within the education sector worldwide. Therefore, it is necessary for universities to monitor the activities of other institutions serving export markets. In addition, in targeting a number of foreign markets with perhaps different cultural regulatory environments and different requirements for the job market, higher education institutions sometimes struggle to recognise and embrace the different needs of these markets. It is in this context that universities are trying to implement strategic marketing to prosper and in some cases to survive in the current competitive marketplace for higher education. Despite the importance of export markets in the higher education marketplace, no research has hitherto investigated the conceptualisation of EMO in a higher education context.

There are few studies on some aspects of international marketing in universities (e.g., Gomes and Murphy, 2003; Russell, 2005, Shah and Laino, 2006). For example, Mazzarol (1998), Mazzarol and Soutar (2002), Binsardi and Ekwulugo (2003) and Russell (2005) studied factors influencing the decision process of international students in selecting a study destination. However, most of this literature is general, as it examines some of the general principles of marketing (e.g., purchase decision process), rather than tapping the specificities of export marketing.

There is also a dearth of research examining strategic themes of the export marketing of higher education. Vauterin et al. (2011) applied the relationship marketing paradigm to higher education. The authors presented a view of market orientation in universities as building strategic relationships with industry. While the study solely focus on one aspect of the market (i.e. industry), it overlooks other players in the international education environment (e.g. students). In addition, the study draws upon models of general marketing (i.e. relationship marketing) and misses to contextualise market orientation in an international setting. Another study that offers a strategic lens to the literature of international marketing of higher education is Shah's and Laino (2006). The authors applied the model of adaptation versus standardisation to communications strategies to prospective international students. Although, Shah and Laino's (2006) study is the first to use this model of export marketing strategy, the study overemphasises the contingencies with regards to how much to standardise or adapt. The model disregards the nature of export marketing activities which should be carried out. None of the studies examined managers' perceptions of the export marketing behaviour in higher education institutions. Specifically, the conceptualisation of EMO (referring to the implementation of export marketing) in the educational setting has not been examined. Therefore, this study aims to explore how 
universities management perceive and manage marketing activities towards their export markets in the context of international students' recruitment.

\section{Methodology}

The authors chose the qualitative method to obtain rich and detailed information on how universities perceive and manage EMO in the context of international students' recruitment. A qualitative method was deemed as more appropriate given the nontypical and under-researched context of the study. Qualitative method allows a deeper understanding of the research problem as well as uncovering contextual peculiarities (Silverman, 2000; Eisenhardt and Graebner, 2007). More specifically, we adopt a case-based exploratory approach. Past research on export marketing for universities is scarce, and in cases where little is known about the phenomenon to be investigated, case-based exploratory research is recommended (Ghauri, 2004). In addition, the focus on the implementation of export marketing behaviour in universities required the authors to capture multiple aspects of practice and process. Semi-structured in-depth personal interviews with key informants were used as the data collection method in order to allow for discussions and follow-up questions. In depth personal interviews allow "insight into the respondents' own interpretations of their environments and improves the researcher's possibility of understanding underlying or latent constructs" (Miles and Huberman, 1994 cited in Toften and Hammervoll, 2009, p. 1382). Management members of the international office are therefore well positioned to address export-specific issues. The decision to use semi-structured interviews was based on the fact that the literature into EMO is fairly well established. The literature review on EMO yielded generic themes that have been used to guide the interviews. The interview guide (appendix 1) was important in that it provided the focus for discussion. The interview questions included the following three major themes: (1) exporting, (2) EMO, and (3) export performance.

Post-92 UK universities provide a rich context for understanding the phenomenon under study. This generation of UK universities are generally teaching-focused export institutions (Fullwood et al., 2013) operating commercially in the global market and catering to a lower cost/lower quality echelon of foreign education (Marginson, 2006). It is widely acknowledged that research income is on average more than 10 times higher for pre-92 than for post-92 universities (Blass et al., 2010). Therefore, the strategic choices of post-92 universities tend to be driven more by teaching income including income from international students than in the case of pre-92 institutions. In addition, post-92 universities are more vocationally oriented and hence more market oriented with a focus on programmes that are responsive to market needs (Smith and Preece, 2009). Post-92 universities have often witnessed the biggest increase in diversity of students in terms of ethnic backgrounds (Read et al., 2003; Molesworth et al., 2010). This reveals that these universities are actively engaged in internationalisation and exporting activities. Export marketing is assuming a position of increasing importance, with universities seeking to develop a "brand" to attract students, staff and funding (Rolfe, 2003) given that "such universities do not have the luxury of the older, established universities who can fall back on their reputations" (Rolfe, 2003, p.40). 
We adopted a literal replication approach where the cases predicting similar results were selected (Yin, 1998, Alam, 2005). This allowed the emergence of a consistent theme and therefore more coherent findings (Yin, 2003). We followed this approach because we sought to gain insight into the practices of export-market leading universities. Purposeful sampling was used to select cases with an established international office, a strong export dependency represented by the percentage of university revenues from international sources as well as the number of international students recruited. Another criterion of selection was a high breath of export referring to the number of overseas countries from which the university recruit students. The cases selected were based on the suggestions and information from the British Universities International Liaison Association (BUILA) and also on availability and willingness to disclose data and on a theoretical basis. This resulted in a sample of 8 post-92 UK universities. Table 1 provides a profile of these universities. Twenty interviews were conducted with an average length of 90 minutes, and respondents included heads of international offices, international marketing directors, regional directors and senior international officers.

Before each interview, we searched for the university background, information about international student recruitment, international marketing activities available on the university website as well as press releases and other secondary data sources. Triangulation of information was conducted by comparing information acquired from respondents with information from written documents and websites. In addition, this information was used to probe for details and to aid and check respondents' recall of events.

Table 1: Profile of universities

\begin{tabular}{|c|c|c|c|}
\hline University & $\begin{array}{c}\text { Percentage of } \\
\text { international students }\end{array}$ & $\begin{array}{c}\text { Export dependency } \\
(\%)\end{array}$ & Breath of export \\
\hline U1 & 20 & 28 & 142 \\
\hline U2 & 25 & 26 & 115 \\
\hline U3 & 27 & 16 & 102 \\
\hline U4 & 39 & 27 & 135 \\
\hline U5 & 24 & 19 & 82 \\
\hline U6 & 32 & 21 & 127 \\
\hline U7 & 25 & 18 & 94 \\
\hline U8 & 22 & 20 & 87 \\
\hline
\end{tabular}

During the interviews, care was taken to allow respondents to deepen and clarify their views. Prompts such as: "this was interesting, can you further describe ..." were frequently given to obtain the necessary information. At the end of each interview the main findings were summarised and provided to the informants for feedback and potential adjustments. The interviews were taped and subsequently transcribed. We 
used a software program called NVivo which is designed to analyse qualitative data. The analysis, interpretations were then independently reviewed by at least two researchers. The analysis followed the principles of content analysis. Content analysis involves "identifying, coding, categorising, classifying, and labelling the primary patterns in the data" (Patton, 2002:463). Based on the categories extracted from the literature on EMO, interviews were then analysed primarily by deductive content analysis (Hinkin, 1995; Krippendorff, 1980). The use of the literature and theory was a departing point of the analysis. Following this method, relevant themes were extracted from interviews and compared with themes preconceived from the literature (Easterby-Smith et al., 1991). Information generation, dissemination, responsiveness, and export performance set the background for coding and analysing the data. These variables represent the start list of codes (Miles and Huberman, 1994). The start list served as a reference to the qualitative data. However, in addition to predominantly applying deductive content analysis, we have adopted inductive content analysis to some extent since some new aspects and themes emerged during the analysis. The process of data analysis involved first disaggregating the qualitative data collected into significant and related groups through open coding. Themes from the data were contrasted with the start code list. Texts from the interviews were reviewed individually and coded to either the start list or new codes were developed as the understanding of the data increased (Lincoln and Guba, 1985). The second phase refers to axial coding. The synthesis and reorganisation of coded categories led to the development of themes and patterns which can be confronted by existing theories (Collis and Hussey, 2003). Subsequently, the researchers used selective coding to specify relationships between constructs (Spiggle, 1994). The criteria for assessing the trustworthiness of the study and findings are therefore considered fulfilled regarding credibility, confirmability and integrity (Weber, 1985; Boeije, 2002). These criteria are important for this type of research (Fugate et al., 2006).

\section{Findings}

We have organised our findings under four broad themes. We identified dominant themes through pattern coding across cases. The four themes are 'Exporting in universities', 'EMO in universities', 'University ranking position', and 'University export performance'. The first theme delineates how university management perceives the notion of exporting of educational services. This is a key theme as the concept of exporting may not be evident in a peculiar context (i.e. higher education). The second theme helps us understand the key elements of EMO in universities, and is divided into two sub-themes: 'Outlook of the export market' and 'Information based activities'. The third theme identifies university ranking position as a potential driver of EMO. The fourth theme helps in understanding the usefulness of EMO in universities.

\section{Exporting in universities}

The interviewees' understanding of exporting in universities is in line with the conceptualisation from literature (Roberts, 1999; Lewis, 2005). They perceive the activity of exporting higher education services consisting of the following categories:

- Cross-border delivery: through distance education. 
- Inbound delivery: international students' recruitment.

- Outbound delivery: delivery of offshore education.

Universities are in different stages of internationalisation. Some have reached the most advanced stage of exporting their educational services through setting up their own branch campuses overseas. One manager stated:

Yes, we have all three; we are involved in all the methods of export mentioned. (Interviewee 3).

Others are in an early stage of the internationalisation process through a traditional mode of export. Most, if not all, of the universities interviewed focus heavily on the inbound delivery as their primary export mode. This represents the focus of the analysis. One manager's response was:

I would say we mainly do the inbound. In terms of the outbound, overseas campuses, our university has not really gone down that route. I do not see that it is going to do in a foreseeable future, but that does not mean that it will not do at some point, but at the moment it is concentrating very much on the inbound.

(Interviewee 9).

\section{EMO in universities}

\section{Outlook of the export market (out-in approach)}

As opposed to a product orientation (Sharp, 1991), the participants perceive EMO in universities as based on a view of the export market. In this context, the starting point is the market. Therefore, market needs are expected to stimulate the university to react with its services. This is consistent with the literature on MO (e.g., Narver and Slater, 1990; Kohli and Jaworski, 1990) maintaining that "market orientation is prevalent when information concerning customers guides, product development and marketing efforts" (Wood and Bhuian, 1993, p.9). Below is a comment reflecting this idea:

Export market orientation requires that the market research that is done needs actually to have a huge amount of influence on courses' design...We should start from market needs rather than the product.

(Interviewee 5)

In addition to the participants' perceptions of EMO as based on a view of the export market, some of the participants maintained that they are fairly export market oriented. 
Foreign market demand does influence course design. Like we saw that in India, we do lot of biomedical science courses and there was a big demand for drug development and discovery, so as a result of seeing that in the market, we have developed that course.

(Interviewee 14)

\section{Information based activities}

In accordance with the international business literature (e.g., Cadogan and Diamantopoulos, 1995; Diamantopoulos and Cadogan, 1996) as well as the higher education marketing literature (Stewart, 1991; Caruana et al., 1998a;b), the interviews illustrated EMO in universities as consisting of information-based activities geared towards foreign markets. The respondents perceive EMO information based activities as consisting of superior knowledge and awareness of the market components as well as a constant surveillance of the market. A director of the international office reflected this idea:

I think market orientation is about knowing your product: it should be about knowing who your competitors are, and I think one of the most interesting things at the moment is the changing nature of the customer, the very rapidly changing nature of the customer, and by customer, I mean students.

(Interviewee 10)

This involves ongoing market research analysis and planning in order to align university's efforts with the expectations of its foreign markets. One interviewee reflected this idea:

Just taking snapshots every year even it is just not good enough, it should be something that is absolutely ongoing if this market research is going to be worth anything. And it needs people not just taking snapshots but actually looking at the implications and projecting forward and using judgements if we are going to be cutting edge.

(Interviewee 2)

Effective export market research analysis and planning requires relevant export market information generation and dissemination within the university. The respondents also commented on the way they carry out export market information generation and dissemination. The generation of market intelligence pertains to the needs and expectations of potential and current international students (e.g., details of courses, fees), as well as the different market trends (e.g., competition, regulation, technological, political and economic developments) characterising the university's export environment. For example, a marketing manager stated:

For prospective international students, obviously what we are looking at is which courses are they interested in? What are their main motivating factors? Why do they want to come and study in the UK? ... And in terms of what the 
students want when they get here, that's certainly services. We run some focus groups with students every now and again. We also try to keep up with the global picture by keeping in touch with the news and the general economic and political picture of the world as much as we can.

(Interviewee 13)

Furthermore, when asked about the process of generating relevant market intelligence, a deputy at the international office stated:

We clearly do secondary data collection in terms of the data available from the British Council, from UCAS, we work mainly through partnerships overseas... there is also information gathering during my visits out there.

(Interviewee 9).

Another aspect of EMO in universities relates to the dissemination of relevant intelligence throughout the university, essentially between the international office and different schools/departments. For example, according to one senior international officer:

Usefully we do have an international committee that meets regularly; representatives of the committee are from faculties, the services (registry, accommodation and finance) and the international office, and that's a forum for sharing information and discussion about the international activity...

(Interviewee 17)

In addition, the interviews captured another important component of EMO in universities: the university ability to respond to export market needs in a timely fashion. The respondents perceive responsiveness as an important dimension of EMO in universities (Cadogan et al., 1999).

I think this whole idea of having a market orientation means that you can react quickly with your product and respond to the market.

(Interviewee 3)

While there has been a consensus among respondents on the notion of responsiveness in universities in that it entails designing and implementing necessary actions in order to meet the needs of its export markets, the quotes below reveal a divergence in the level of responsiveness carried out by different universities.

Unfortunately most universities are slow organisations and do not necessarily react quickly with the product. Responsiveness needs various bits of the university all coming together and that does not work very well, particularly in a very big university because there are 6 or 7 different departments and you cannot get them all to think the same way or react quickly.

(Interview 3) 
I don't think we are very responsive to foreign markets, I think it is more about what heads of schools want, academics expertise and what courses are in place which may make changes very difficult. Responsiveness may involve change and universities in general don't like change.

(Interview 1)

If there are some areas where we are not performing very well then we put a kind of taskforce into place to try and improve that. For example, last year in the barometer survey, we came out really badly for Internet access and it was really affecting students' experience. So we have made lot of changes to sort out that problem.

(Interviewee 6)

Compared to some other universities we are quick in developing new courses, last year there was a demand for a specialised programme in IT from China and India so in 6 months the programme was ready! Well they want the students! So we have to react quickly.

(Interviewee 19)

\section{University ranking position}

A key issue raised during the interviews is the importance of university ranking position. For example, some of the respondents noted that:

One thing that has become so big over the last 5 to 10 years is rankings, almost to the point [of being] ridiculous. In so many countries one of the questions that you get asked is "Where are you ranked? Where are you ranked as an institution?" And that is all they are thinking about. And it did not use to be like that. But [rankings] are definitely a big big thing.

(Interviewee 20)

Ranking is hugely important because many overseas students look at the Times University Guide (national ranking system) and assess which university is right for them...

(Interviewee 12)

In addition to the anecdotal evidence that university recruiters are increasingly questioned by potential international students regarding the university national ranking position, there is general consensus among scholars and managers that ranking systems influence students' choice of a particular institution (e.g., Filinov and Ruchkina, 2002; Thakur, 2007; Hazelkorn, 2013). This is particularly the case for 
international students where status and prestige are significant considerations in decision-making (Hazelkorn, 2007). Therefore lower-ranked universities find themselves at a disadvantage when recruiting international students. This is in line with some of the respondents' comments.

We are sort of very much behind. We are ... a low league table position which puts us at a disadvantage in open recruitment.

(Interviewee 18)

Because our position in the league table needs to be improved then foreign markets, which are ranking conscious, are not going to come to our university even though there might be large numbers studying in the UK.

(Interviewee 7)

It can be inferred that university managers are required to take their ranking position into account in their international marketing strategy given the impact of ranking position on international students' decision-making. This is consistent with Thakur (2007) maintaining that rankings are influencing decision-making and planning process within universities (Hazelkorn, 2013). In this context, lower-ranked universities are expected in particular to be more market oriented towards their export markets than the more prestigious institutions "which can just rely on their prestige" (Marginson, 2006, p. 8). A head of international marketing and admissions stated:

You generally find the post-1992 are probably more likely to be doing EMO and the older, more prestigious universities are less likely to be involved in that....

(Interviewee 15)

This can be explained by the next comment by a senior international officer:

Sometimes ranking does not give a fair impression of the university. You have to counteract it and say no, we have some fantastic courses...

(Interviewee 11)

As university ranking position is not always a true depiction of university quality (Dill and Soo, 2005), marketing effort is needed as a formal way of communicating the qualities of a university, particularly in the case of a lower-ranked university. Thus, a lower university ranking position is found as a driver of EMO.

\section{Usefulness of EMO}

All participants stated that a desired outcome of pursuing EMO is to enhance their performance towards foreign markets. Some respondents commented on this relationship as follows: 
Performance is definitely an outcome of marketing our services to different foreign markets.

(Interviewee 19)

We allocate a budget for these marketing activities: going abroad for exhibitions is an example, so we obviously want something in return for these expenses. The more we spend on a market, the more we want and expect in terms of better performance.

(Interviewee 8)

When asked to provide a meaning to the export performance of universities, international marketing managers perceive the export performance of universities primarily as a business performance. All participants agree on the primacy of numbers; their initial responses were as follows:

Numbers, sales if you like, no I would not call it sales, but we have to achieve a target, a number of students or an income target. We get something like 24 million so we have to achieve this target, I feel that it is the only target that matters, everything else is point... secondary to that.

(Interviewee 14)

The marketing managers are trying to bring in as many students from their region as they can.

(Interviewee 16)

These comments are in line with the literature of higher education marketing, which considers international higher education as a large business (Coate et al., 2001). International higher education has gradually been discovered as a lucrative service industry and export commodity (Martens and Starke, 2008). In this respect, Ivy (2001) supports the legitimacy of adopting the business philosophy in the higher education sector. In particular, some studies (e.g., Caruana et al., 1998a; Binsardi and Ekwulugo, 2003) advocate the usefulness of measuring the business performance of universities.

Like the work of Zajac and Kraatz (1993), the findings revealed the primacy of both financial and customer-based indicators in measuring the business performance of universities. In an export setting, a key financial measure of university business performance is considered to be the revenues from international students. A senior international officer stated: 
Every international office would have to be honest and say that a major factor in recruiting an international student is the income that an international student brings in. This is an income that the university can spend in whatever way it chooses.

(Interviewee 11)

Customer-related measures include customer acquisition, market share, and customer satisfaction (Kaplan and Norton, 2001). Similarly, when considering the international student as the primary customer of the university, managers perceived the following as export performance indicators:

-Enrolment volume of international students. When asked to provide measures for export performance, one head of the international office stated:

Number of students, as simple as that!

(Interviewee 2)

-Market share of international students relative to other universities. An example of the comments is:

We regularly monitor the HESA statistics of international student numbers and our overall position. I guess we would aim to be in the top 20.

(Interviewee 4)

-International students' satisfaction. One manager confirmed this idea:

International students' satisfaction would be an indicator of performance and we do undertake a survey of our students regularly.

(Interviewee 5)

Our data shows that university export performance is a desired outcome of EMO.

\section{Discussion}

The study's aim was to shed light through empirical insights on a relatively unexplored export market reality, which affects a large number of universities in a number of countries. Notwithstanding the importance of the export market in shaping the direction of higher education marketing (De Vita and Case, 2003; Russell, 2005), there is little research investigating the significance of EMO in the higher education context. Few studies examined the applicability of MO in a higher education setting (Stewart, 1991; Caruana et al., 1998a; Wasmer and Bruner, 1999). Nevertheless, insufficient empirical research has been carried out on $\mathrm{MO}$ in higher education institutions from an international perspective. Therefore, this study attempted to achieve a meaningful level of understanding of the EMO construct in universities. 
In accordance with the international business literature (e.g., Cadogan and Diamantopoulos, 1995; Diamantopoulos and Cadogan, 1996) as well as the higher education marketing literature (Stewart, 1991; Caruana et al., 1998a;b), the interviews illustrated EMO in universities as consisting of information-based activities geared towards foreign markets. Superior knowledge and awareness of the market components is central to the implementation of these information-based activities (Kohli and Jaworski, 1990). This involves market information generation and dissemination, as well as the need for rapid responsiveness due to the changing nature of the market.

Universities that are responsive to the complex nature of the international environment proactively engage in market intelligence generation. They collect relevant secondary data from higher education bodies/organisations (e.g., Higher Education Statistics Agency HESA), education partners and agents overseas, and analyse figures from prior performance. Moreover, these export-market oriented universities periodically review the likely effect of changes in key market trends (e.g., competition, regulation, technological, political and economic developments) characterising the university's export environment. In addition to secondary data, proactive universities regularly carry out market research through primary data collection (surveys, focus groups with international students) and participate in international fairs overseas in order to track the different needs of students from different countries. Additionally, these relevant data are disseminated within the university and reinforced through enhanced levels of inter-functional coordination. Coordination activities refer to continuous liaison essentially between the international office and different schools/departments through formal (meetings, reports, intranet portal) and informal means (as part of everyday communication) to share key foreign markets trends and developments.

The interviews captured another important component of EMO in universities. University responsiveness entails designing and implementing necessary actions in order to meet the needs of its export markets. For example, when sensing a market need for a particular programme or service, export market oriented universities implements the course/service in a timely fashion in order to respond to foreign market trends.

Although the interviewees agreed on the notion of EMO in universities as consisting of information generation, dissemination and responsiveness, the respondents reveal discrepancies in the level of adoption of EMO. This is particularly the case for responsiveness. While some universities acknowledge that they are rather slow moving organisations with an approach to courses' design based on availability and academic expertise rather than responding to market needs, others tend to design and offer services as a response to the needs of their export markets.

Our study illustrates how EMO in universities may be shaped by university ranking position. Our findings show that higher ranked universities are expected to be less export market oriented given that they can rely solely on their prestige to attract international students (Marginson, 2006). Conversely, post-1992 universities (generally lower ranked) tend to favour a market-driven model of higher education. In addition, post-92 universities are more involved in entering and serving foreign markets, in particular the markets that are less ranking conscious, bearing in mind that the domestic market is usually more perceptive of national ranking systems. Our findings are in line with Cadogan's et al. (2002) study supporting a negative correlation 
between export experience (i.e., the number of years the firm has been exporting) and EMO. Older and well-established universities with longer export experiences consistently rank higher than post-1992 universities with generally a relatively emergent exporting activity (Hazelkorn, 2008).

Prior literature has indicated a gap with regards to university performance from a managerial perspective (Zajac and Kraatz, 1993; Caruana's et al., 1998a). The present study provided a new outlook in conceptualising export performance in higher education as a business/organisational performance. International marketing managers perceive university export performance as consisting of enrolment volume, revenues, relative market share and international students' satisfaction aspects. Findings also confirm the view that a market oriented approach is indeed in line with high performance. This view has been suggested both in the domestic higher education literature (Caruana et al., 1998a; b) and international literature (Cadogan et al. , 2002; Rosé and Shoham, 2002). EMO activities will enable international marketing managers of universities to become well-informed as well as to monitor any changes that the export market undergoes. Likewise, Mazzarol and Hosie (1996) highlighted the significance of information gathering, dissemination and responsiveness by universities in developing a quality image and therefore in achieving a sustainable competitive advantage in international education. As a result, a high level of EMO may be expected to enhance the enrolment volume of international students and thereby boost universities' revenue from international students.

The findings suggest some possible implications for international marketing managers. With the increasing liberalisation of higher education and the development of a market-driven transnational education, universities should seek information, identify global opportunities, and react to information on an international basis. The adoption of EMO seems valuable as by becoming more export market oriented, universities strive to achieve a better performance in terms of revenues, market share and students' satisfaction.

International marketing managers of lower-ranked universities should not be discouraged by their position. Rather, through implementing export marketing, they should be encouraged to compete on an international scale while putting an emphasis on their assets (e.g., the ranking of a specific school/subject or any other qualities that can serve as a competitive advantage).

\section{Limitations and future research}

One obvious limitation of this paper stems from the intrinsic nature of qualitative research in terms of generalisability of findings. As such, the findings are only indicative and may not be generalisable to all exporting universities. Therefore, future work is needed to validate these findings. In addition, the qualitative data revealed performance as merely a desired outcome from adopting EMO. Hence, future quantitative studies could examine the effect of EMO on performance in universities. Another interesting avenue for future research may be to investigate key drivers to EMO in universities. This could give some indication to the reasons behind the discrepancies in the level of EMO/responsiveness adopted. 
This study was developed from a managerial perspective only. One potentially fruitful avenue for further research is to explore the academics' perceptions of EMO in universities considering that academics are influential stakeholders in higher education institutions. Academics' adherence to EMO is essential as the effective implementation of export marketing activities needs the coordination of all departments and schools/faculties. This contribution will help different types of managers in universities to understand the important role of EMO and its dimensions as well as support its implementation. In parallel to that, conceptualising performance as academic quality and examining the effect of EMO on academic quality would be another area worth consideration. Probably integrating/contrasting academic and business measures would give a more comprehensive understanding of university export performance.

The study was cross-sectional so another potential research direction is to explore how EMO changes over time with the development of a more market-led environment where students are gaining more bargaining power. 


\section{References}

Alam, I. (2005), "Fieldwork and data collection in qualitative marketing research", Qualitative Market Research: An International Journal, Vol. 8 No.1, pp. 97-112.

Binsardi, A. and Ekwulugo, F. (2003), "International marketing of British education: Research on the students' perception and the UK market penetration", Marketing Intelligence and Planning, Vol. 21 No. 4/5, pp. 318-327.

Blass, E., Jasman, A. and Shelley, S. (2010), "Visioning 2035: the future of the higher education sector in the UK, Futures, Vol. 42 No. 5, pp. 445-453.

Boeije, H. (2002), "A purposeful approach to the constant comparative method in the analysis of qualitative interviews", Quality and Quality, Vol. 36, pp. 391-409.

Bragg, S. (2007), "Student voice and governmentality: the production of enterprising subject", Discourse: Studies in the Cultural Politics of Education, Vol. 28 No. 3, pp. 343-355.

Cadogan, J.W. and Diamantopoulos, A. (1995), "Narver and Slater, Kohli and Jaworski and the market orientation construct: integration and internationalization", Journal of Strategic Marketing, Vol. 3 No. 1, pp. 41-60.

Cadogan, J.W., Diamantopoulos, A. and De Mortanges, C. (1999), "A measure of export market orientation: scale development and cross-cultural validation", Journal of International Business Studies, Vol. 30 No. 4, pp. 689-707.

Cadogan, J.W. Paul, N., Salminen, R., Puumalainen, K. and Sundqvist, S. (2001), "Key antecedents to "export" market-oriented behaviours: a cross-national empirical examination", International Journal of Research in Marketing, Vol. 18 No. 3, pp. 261282.

Cadogan, J.W., Sundqvist, S. and Salminen, N. (2002), "Export market-oriented activities: their antecedents and performance consequences", Journal of International Business Studies, Vol. 33 No. 3, pp. 615-626.

Cadogan, J.W., Sundqvist, S., Salminen, R. and Puumalainen, K. (2000), "The relative explanatory value of export market orientation: comparing across business contexts", paper presented at the Australian and New Zealand marketing conference (ANZMAC), 28 November-1 December, Queensland, available at:http://anzmac.info/conference/2000/CDsite/papers/c/Cadogan1.PDF (accessed 19 March 2010).

Cadogan, J. W., Kuivalainen, O. and Sundqvist, S. (2009), "Export Market-Oriented Behavior and Export Performance: quadratic and moderating effects under differing degrees of market dynamism and internationalization", Journal of International Marketing, Vol. 17 No. 4, pp. 71-89.

Caruana, A., Ramaseshan, B. and Ewing, M. (1998a), "Do universities that are more market orientated perform better?", International Journal of Public Sector Management, Vol. 11 No. 1, pp. 55-70. 
Caruana, A., Ramaseshan, B. and Ewing, M. (1998b), "The market orientationperformance link: some evidence from the public sector and universities", Journal of Nonprofit and Public Sector Marketing, Vol. 6 No. 1, pp. 63-82.

Castle, B. (2005), "Introduction to web services for remote portlets", available at: http://www-128.ibm.com/developerworks/library/ws-wsrp/ (accessed 12 November 2007).

Clark, T., Rajaratnam, D. and Smith, T. (1996), "Toward a theory of international services: marketing Intangibles in a world of nations", Journal of International Marketing, Vol. 4 No. 2, pp. 9-28.

Coate, K., Barnett, R. and Williams, G. (2001), "Relationships between teaching and research in higher education in England ", Higher Education Quarterly, Vol. 55 No. 2, pp. 158-174.

Collis, J. and Hussey, R. (2003), Business research: a practical guide for undergraduate and postgraduate students (Second edition), Palgrave MacMillan.

Conway, T., Mackay, S. and Yorke, D. (1994), "Strategic planning in higher education: Who are the customers?", International Journal of Educational Management, Vol. 8 No. 6, pp. 29-36.

Datar, S.M., Garvin, D.A. and Cullen, P.G. (2010), Rethinking the MBA: business education at a crossroads, Harvard University Press, Boston.

Desmarez, P. and Thys-Clement, F. (1994), "Universities, students and employment: present position and prospects", Higher Education Management, Vol. 6 No. 3, pp. 259273.

De Vita, G. and Case, P. (2003), "Rethinking the internationalisation agenda in UK higher education", Journal of Further and Higher Education, Vol. 27 No. 4, pp. 383398.

Diamantopoulos, A. and Cadogan, J.W. (1996), "Internationalising the market orientation construct: an in-depth interview approach", Journal of Strategic Marketing, Vol. 4, pp. 23-52.

Dill, D. and Soo, M. (2005), "Academic quality, league tables, and public policy: a cross-national analysis of university ranking systems", Higher Education, Vol. 49 No.1, pp. 495-533.

Easterby-Smith, M., Thorpe, R., and Lowe, A. (1991), Management research: An introduction, Sage, London.

Eisenhardt, K.M. and Graebner, M.E. (2007), "Theory building from cases: opportunities and challenges", Academy of Management Journal, Vol. 50 No. 1, pp. 25-32.

Filinov, N. and Ruchkina, S. (2002) "The ranking of higher education institutions in Russia: some methodological problems", Higher Education in Europe, Vol. 27, pp. 407-421. 
Fugate, B., Sahin, F. and Mentzer, J.T. (2006), "Supply Chain Management Coordination Mechanisms", Journal of Business Logistics, Vol. 27 No. 2, p.129-161.

Fullwood, R., Rowley, J. and Delbridge, R. (2013) "Knowledge sharing amongst academics in UK universities", Journal of Knowledge Management, Vol. 17 No. 1, pp.123-136.

Ghauri, P.N. (2004), "Designing and conducting case studies in international business research", in Marschan-Piekkari, R. and Welch, C. (Ed.), Handbook of qualitative research: methods for international business, Edward Elgar, Cheltenham, England, pp. 109-124.

Gomes, L. and Murphy, J. (2003), "An exploratory study of marketing international education online", International Journal of Educational Management, Vol. 17 No. 3, pp. 116-125.

Gürüz, K. (2012), Higher education and international student mobility in the global knowledge economy, State University of New York Press, NY.

Harman, G. (2004), "New directions in internationalizing higher education: Australia's development as an exporter of higher education services", Higher Education Policy, Vol. 17 No. 1, pp. 101-120.

Hazelkorn, E. (2007), "Learning to live with league tables and ranking: the experience of institutional leaders", Higher Education Policy, Vol. 21 No.1, pp. 193-215.

Hazelkorn, E. (2013), "How rankings are reshaping higher education in Climent, V., Michavila, F. and Ripolles, M. (eds): Los Rankings Univeritarios: Mitos y Realidades, Ed. Tecnos, 2013.

Hemsley-Brown, J. and Oplatka, I. (2006), "Universities in a competitive global marketplace", International Journal of Public Sector Management, Vol. 19 No. 4, pp. 316-338.

Ho, H. and Hung, C. (2008), "Marketing mix formulation for higher education", International Journal of Educational Management, Vol. 22 No. 4, pp. 328-40.

Inglis, R.M. (2008), "Exploring accounting and market orientation: an interfunctional case study", Journal of Marketing Management, Vol. 24 No. 7/8, pp. 687-710.

Ivy, J. (2001), "Higher education institution image: a correspondence analysis approach", The International Journal of Educational Management, Vol. 15 No. 6, pp. 276-282.

Jaworski, B. and Kohli, A. (1993), "Market orientation: antecedents and consequences", Journal of Marketing, Vol. 57 No. 3, pp. 53-70.

Kaplan, R. and Norton, D. (2001), "Transforming the balanced scorecard from performance measurement to strategic management", Accounting Horizons, Vol. 15 No. 1, pp. 87-104.

Knight, J. (2003), "GATS, trade and higher education: Perspective 2003: where are we?"

available 
at:http://200.229.43.1/imagedb/documento/DOC DSC NOME ARQUI20060214115 610.pdf (accessed 12 November 2010).

Kohli, A. and Jaworski, B. (1990), "Market orientation: the construct, research propositions, and managerial implications", Journal of Marketing, Vol. 54 No. 2, pp. 118.

Leonidou, L., Katsikeas, C. and Coudounaris, D. (2010), "Five decades of business research into exporting: a bibliographic analysis", Journal of International Management, Vol. 16 No. 9, pp. 78-91.

Lincoln, Y. and Guba, E. (1985), Naturalistic Inquiry, Sage, Beverly Hills, CA.

Lomas, L. (1997), "The decline of liberal education and the emergence of a new model of education and training", Education and Training, Vol. 39 No. 3, pp.111-115.

Marginson, S. (2006), "Dynamics of national and global competition in higher education", Higher Education, Vol. 52 No. 1, pp. 1-39.

Martens, K. and Starke, P. (2008), "Small country, big business? New Zealand as education exporter", Comparative Education, Vol. 44 No. 1, pp. 3-19.

Mazzarol, T. (1998), "Critical success factors for international education marketing", The International Journal of Educational Management, Vol. 12 No. 4, pp. 163-175.

Mazzarol, T. and Hosie, P. (1996), "Exporting Australian higher education: future strategies in a maturing market", Quality Assurance in Education, Vol. 4 No. 1, pp. 3750.

Mazzarol, T. and Soutar, G. (2002), "Push-pull factors influencing international student destination choice", The International Journal of Educational Management, Vol. 16 No. 2, pp. 82-90.

Miles, M.B. and Huberman, A.M (1994), Qualitative data analysis, Sage Publications Ltd, Thousand Oaks, CA.

Molesworth, M., Scullion, R. and Nixon, E. (2011), The marketisation of higher education and the student as consumer, Routledge, NY.

Moogan, Y.J. (2011), “Can a higher education institution's marketing strategy improve the student-institution match?" International Journal of Educational Management, Vol. 25 No. 6 , pp. 570-589.

Narver, J. and Slater, S. (1990), "The effect of a market orientation on business profitability", Journal of Marketing, Vol. 54 No. 3, pp. 20-35.

Paswan, A. and Audhesh, G. (2009), "Higher education institutions: satisfaction and loyalty among international students", Journal of Marketing for Higher Education, Vol. 19 No. 1, pp. 65-84.

Patton, M. (2002), Qualitative Research and Evaluation Methods (3rd ed.), Sage Publications, Thousand Oaks, CA. 
Read, B., Archer, L. and Leathwood, C. (2003), "Challenging cultures? Student conceptions of 'belonging' and 'isolation' at a post-1992 university", Studies in Higher Education, Vol. 28 No. 3, pp. 261-277.

Roberts, J. (1999), "The internationalisation of business service firms: A stages approach", The Service Industries Journal, Vol. 19 No. 4, pp. 68-88.

Rolfe, H. (2003), "University strategy in an age of uncertainty: the effect of higher education funding on old and new universities", Higher Education Quarterly, Vol. 57 No. 1 , pp. 24-47.

Rosé, G. and Shoham, A. (2002), "Export performance and market orientation: establishing an empirical link", Journal of Business Research, Vol. 55 No.3, pp.217225.

Russell, M. (2005), "Marketing education: A review of service quality perceptions among international students", International Journal of Contemporary Hospitality Management, Vol. 17 No. 1, pp. 65-77.

Shah, A. and Laino, H. (2006), "Marketing a U.S. university to international students: which approach is best-standardisation, adaptation, or contingency? An investigation of consumer needs in seven countries", Journal of Marketing for Higher Education, Vol. 16 No. 1, pp. 1-24.

Sharp, B. (1991), "Marketing orientation: more than just customer focus", International Marketing Review, Vol. 8 No. 4, pp. 20-25.

Silverman, D. (2000), Doing qualitative research: a practical handbook, Sage Publications Ltd, London.

Smith, P. and Preece, D. (2009), "Postgraduate work-based learning programmes in English higher education", Journal of Vocational Education and Training, Vol. 61No. 2, pp. 169-182.

Souchon, A. and Diamantopoulos, A. (1996), "A conceptual framework of export market information use: key issues and research propositions", Journal of International Marketing, Vol. 4 No. 3, pp. 49-71.

Spiggle, S. (1994), "Analysis and interpretation of qualitative data in consumer research", Journal of Consumer Research, Vol. 21 No. 3, pp. 491-503.

Stewart, K. (1991), "Applying a marketing orientation to a higher education setting", Journal of Professional Services Marketing, Vol. 7 No. 2, pp. 117-124.

Strauss, A. and Corbin, J. (1998), Basics of qualitative research: grounded theory procedures and techniques, Sage Publications Ltd, Thousand Oaks, CA.

Thakur, M. (2007), "The impact of ranking systems on higher education and its stakeholders", Journal of Institutional Research, Vol. 13 No. 1, pp. 83-96.

Toften, K. and Hammervoll, T. (2009), "Niche firms and marketing strategy: an exploratory study of internationally oriented niche firms", European Journal of Marketing, Vol. 43 No. 11/12, pp.1378-1391. 
Vauterin, J., Linnanen, L. and Marttila, E. (2011), "Customer orientation in higher education: the missing link in international student recruitment? A relationship marketing approach", Industry and Higher Education, Vol. 25 No. 2, pp. 77-91.

Verger, A. (2008), "Measuring educational liberalisation: a global analysis of GATS", Globalisation, Societies and Education, Vol. 6 No. 1, pp.13-31.

Wasmer, D. and Bruner, G. (1999), "The antecedents of the market orientation in higher education", Journal of Marketing for Higher Education, Vol. 9 No. 2, pp. 93-105.

Weber, R. (1985), Basic content analysis, Sage Publications Ltd, Newbury Park, CA.

Wood, V. and Bhuian, S. (1993), "Market orientation and non-profit organisations: performance associations and research propositions", Journal of Nonprofit and Public Sector Marketing, Vol. 1 No. 1, pp. 7-32.

Yin, R.K. (2003), Case study research: design and methods, Sage Publications, Thousand Oaks, CA.

Yokoyama, K. (2008), "Neo-liberal governmentality in the English and Japanese higher education", International Studies in Sociology of Education, Vol. 18 No. 3, pp. 231-247.

Zajac, E. and Kraatz, M. (1993), "A diametric forces model of strategic change: assessing the antecedents and consequences of restructuring in the higher education industry", Strategic Management Journal, Vol. 14 No. S1, pp. 83-103. 


\section{Appendix 1: Interview guide}

This research investigates how universities perceive and manage market orientation in their export operations of educational services to international students (i.e. EMO).

\section{Exporting in universities}

QQ1: What is your understanding of exporting in universities?

The GATS recognise three categories of educational services' exports (i.e. cross-border delivery via distance education for example, delivery of offshore education through branch campuses set overseas, and delivery of education to international students moving to the country of the supplier to receive education).

QQ2: Please indicate your level of agreement with this statement and state why you agree or not agree.

QQ3: Which category of international delivery does your university carry out?

\section{EMO in universities}

QQ4: Will you please give your opinion on the following statement? "EMO in universities refers to the implementation of export marketing" (based on Jaworski and Kohli, 1990; Caruana et al., 1998). Please indicate your level of agreement and state why you agree or not agree.

QQ5: EMO has been defined in academic literature as consisting of three generic activities associated with the generation, dissemination and response to export market intelligence. These activities are oriented towards export customers, competitors, and exogenous market influences (Diamantopoulos and Cadogan, 1996; Cadogan et al., 1999). Do you think that EMO in universities consists of the same activities? If not, please state why not. If yes, how would you categorise and define EMO in universities?

QQ6: What do you think constitutes EMO in universities?

QQ7: What EMO activities does your university carry out?

QQ8: What would you consider as key factors that would encourage universities to pursue an EMO?

QQ9: Based on your experience, how would you describe the higher education environment that may influence the adoption of an EMO?

QQ10: In your opinion, what are the desired outcomes of adopting an EMO?

Export performance has been perceived in academic literature to be the result of the adoption of EMO (Cadogan et al., 2001 and 2002; Rosé and Shoham, 2002). The most widely used dimensions in measuring export performance are: export sales, profit, revenues and customer satisfaction (Zou and Stan, 1994; Katsikeas, 2000; Lawrence and Sharma, 2002).

QQ11: Do you think export performance in universities can be categorised in a similar way? If not, please state how you would categorise and define export performance in universities.

QQ12: Do you think that in the university context, export performance is a potential outcome of EMO? If yes, please state why? If no, please state why not. 